\title{
Global-scale analysis of satellite-derived time series of naturally inundated areas as a basis for floodplain modeling
}

\author{
L. Adam ${ }^{1}$, P. Döll ${ }^{1}$, C. Prigent ${ }^{2}$, and F. Papa ${ }^{3}$ \\ ${ }^{1}$ Institute of Physical Geography, Goethe University Frankfurt, Frankfurt am Main, Germany \\ ${ }^{2}$ Laboratoire d'Etudes du Rayonnement et de la Matière en Astrophysique, Observatoire de Paris, \\ Centre National de la Recherche Scientifique, Paris, France \\ ${ }^{3}$ Columbia University, NASA Goddard Institute for Space Studies, New York, USA
}

Received: 5 February 2010 - Revised: 21 May 2010 - Accepted: 30 May 2010 - Published: 25 August 2010

\begin{abstract}
Floodplains play an important role in the terrestrial water cycle and are very important for biodiversity. Therefore, an improved representation of the dynamics of floodplain water flows and storage in global hydrological and land surface models is required. To support model validation, we combined monthly time series of satellite-derived inundation areas (Papa et al., 2010) with data on irrigated rice areas (Portmann et al., 2010). In this way, we obtained globalscale time series of naturally inundated areas (NIA), with monthly values of inundation extent during 1993-2004 and a spatial resolution of $0.5^{\circ}$. For most grid cells $\left(0.5^{\circ} \times 0.5^{\circ}\right)$, the mean annual maximum of NIA agrees well with the static open water extent of the Global Lakes and Wetlands database (GLWD) (Lehner and Döll, 2004), but in 16\% of the cells NIA is larger than GLWD. In some regions, like Northwestern Europe, NIA clearly overestimates inundated areas, probably because of confounding very wet soils with inundated areas. In other areas, such as South Asia, it is likely that NIA can help to enhance GLWD. NIA data will be very useful for developing and validating a floodplain modeling algorithm for the global hydrological model WGHM. For example, we found that monthly NIAs correlate with observed river discharges.
\end{abstract}

\section{Introduction}

Wetlands play an important role in the terrestrial water cycle, influencing evapotranspiration, water storage and river discharge dynamics. In addition, they are the habitat of a large number of animals and plants. Thus, to assess the

Correspondence to: L. Adam (l.adam@em.uni-frankfurt.de) earth system and its changes, a good understanding of the dynamics of wetlands, including inundated areas, water storages and water flows is required. Global hydrological and land surface models simulate wetlands and seasonally inundated areas with strongly varying degrees of complexity, and some do not simulate them at all. Decharme et al. (2008) described an advanced approach for simulating the inundation of floodplain within a global land surface model, at a spatial resolution of $1^{\circ} \times 1^{\circ}$. In this model, the floodplain reservoir fills when the river height exceeds a critical value. The flooded fraction of the grid cell is determined based on the $1 \mathrm{~km} \times 1 \mathrm{~km}$ Digital Elevation Model HYDRO1k (http://edcdaac.usgs.gov/gtopo30/hydro). With a spatial resolution of $5^{\prime}$ by $5^{\prime}$, Coe et al. (2008) computed the dynamics of flooded areas in the Amazon basin, using basinspecific information on river width, and river stage at which flooding begins as a function of upstream drainage area. To represent sub-grid-scale morphology, a cumulative distribution function was derived from the Shuttle Radar Topography Mission (SRTM) $90 \mathrm{~m}$ elevation data (Farr et al., 2007) (aggregated to $1 \mathrm{~km}$ resolution), and a quantitative relation between inundated areas and water stored in the inundated floodplain was derived.

While the models of Decharme et al. (2008) and Coe et al. (2008) aim at simulating the inundation of floodplains that occurs when river channels can no longer contain all the flowing water, the WaterGAP Global Hydrology Model WGHM (Döll et al., 2003), with a spatial resolution of $0.5^{\circ} \times 0.5^{\circ}$, simulates all types of inland wetlands (including floodplains, freshwater marshes, swamp forests, bogs, fens and salt pans) but does not distinguish among the different types. The location of wetlands and their extent are prescribed by the Global Lakes and Wetlands Database GLWD (Lehner and Döll, 2004). The size of wetlands does not vary

Published by Copernicus Publications on behalf of the European Geosciences Union. 
explicitly over time. However, in the current version of WGHM, evaporation is modeled as a function of water storage, so that wetland area is implicitly assumed to reduce with decreasing storage. Wetland evaporation is reduced by $10 \%$ when actual storage is half of the maximum storage and becomes zero when storage is zero (Hunger and Döll, 2008).

In the Amazon basin, which is characterized by seasonal large-scale inundations of floodplains, WGHM was found to overestimate the lateral transport velocity of water such that seasonal discharge is modeled to peak too early in the year (Döll et al., 2003; Fiedler and Döll, 2010). In addition, compared to seasonal water storage variations as obtained from satellite-derived gravity fields, WGHM underestimates the amplitude of the seasonal water storage variations in the Amazon basin (Fiedler and Döll, 2010; Werth and Güntner, 2010). This may be explained by an underestimation of wetland storage capacity because maximum storage height of wetlands is assumed to be $2 \mathrm{~m}$ globally, a value that is probably too small for the wetlands in the Amazon basin. Therefore, wetland storage in the Amazon basin is fully exploited throughout most of the year. If the river flow velocity is increased by a factor of 3 (or more, depending on the discharge station), a good agreement between observed and simulated seasonality of river discharge and water storage is obtained. This indicates that WGHM might underestimate the storage capacity of the wetlands in the Amazon, and is a motivation for improving the dynamic modeling of wetlands in WGHM, in particular the modeling of floodplains and other wetlands which depend on seasonal river flooding. The development of a new model algorithm requires data of the dynamics of inundation areas, in addition to discharge data and data on total water storage variations in the river basin as provided by satellite-derived gravity fields.

The objective of this study was to analyze time series of inundated areas derived from satellite observations, as a first step towards improved floodplain inundation modeling in WGHM. In Sect. 2, we present a global-scale data set of time series of naturally inundated areas that can be used for developing and validating a floodplain inundation model for WGHM. This data set is based on a monthly time series of inundated areas that was derived from multiple satellites for the time period 1993-2004 (Prigent et al., 2007; Papa et al., 2010). In Sect. 3, we compare this time series with the static wetland extent in the Global Lakes and Wetlands Database GLWD. In Sect. 4, we show a first analysis of the relation between the dynamics of observed river discharge and inundation extent in the Amazon and $\mathrm{Ob}$ river basins, to identify how flooding can be modeled as a function of computed river discharge.

\section{Naturally inundated areas}

A monthly time series of inundated areas for 1993-2004, in percent of total land area, was derived from a multisatellite method employing passive microwave land sur- face emissivities obtained from SSM/I and ISCCP observations, ERS scatterometer responses, and AVHRR visible and near-infrared reflectances. The satellite observations are mapped to an equal area grid with a cell size of $773 \mathrm{~km}^{2}$ $\left(0.25^{\circ} \times 0.25^{\circ}\right.$ resolution at the Equator) (Prigent et al., 2007; Papa et al., 2010). Inundated areas detected by satellites include man-made inundations, in particular those from irrigation of paddy rice. A preliminary exercise was performed by Prigent et al. (2001), subtracting the monthly mean rice field extents provided by Matthews et al. (1991) from the initial satellite-derived estimates. Here, to obtain time series of naturally inundated areas (NIA) that can serve as a basis for validating modeled floodplain inundation dynamics, the extent of irrigated rice as estimated in the MIRCA2000 data set by Portmann et al. (2010) was subtracted from the 19932004 time series of monthly satellite-derived inundated areas. MIRCA2000 is a global data set of monthly irrigated and rainfed crop areas, with a special resolution of $5 \mathrm{arc} \mathrm{min}$. The data set provides growing areas of 26 crop classes for each month of the year, covering all major food crops, cotton, crop categories (perennial, annual, and fodder grasses) as well as multicropping systems and maximizes consistency with census-based national and subnational statistics (Portmann et al., 2010). Irrigated rice areas are not available as time series, but as 12 monthly values that are representative for the situation around the year 2000 such that the same monthly rice area was subtracted for all years. The satellite derived inundated areas of Papa et al. (2010) were upscaled from their original resolution of an equal area grid with a cell size of $773 \mathrm{~km}^{2}$ to the $0.5^{\circ}$ grid cells of WGHM (by intersecting the two grids and calculating an area weighted sum for each $0.5^{\circ}$ cell), while rice areas were upscaled from $5^{\prime}$ grid cells (by aggregation). Please note that the basic statistical information used to derive the seasonality of growing areas in MIRCA2000 is mostly at the spatial scales of countries or regions. Coastal cells (cells not included in the data set of inundated areas (Papa et al., 2010) or not totally covered by the $0.5^{\circ}$ cells of WGHM) have been excluded from the data set due to the fact that satellites observations cannot distinguish between oceans (or large permanent inland water bodies) and inundation areas. Figure 1a shows the mean annual growing area of irrigated rice, with a global value of $0.61 \times 10^{6} \mathrm{~km}^{2}$. Subtracting monthly irrigated rice areas from of satellite-derived inundated areas leads to a reduction of up to $7.8 \%$ in August (the month where the maximum global inundation occurs). Figure $1 \mathrm{~b}$ shows the resulting annual mean of NIA. The overall spatial pattern appears to be plausible, with floodplain inundation of some large rivers like the Amazon and the Paraná being clearly recognizable. Temporal variability of wetlands varies strongly, with low coefficients of variation of the monthly values between 1993 and 2004 occurring in the Amazon basin (Fig. 1c). Very high values of the coefficient of variation generally correlate with low mean annual inundation values. 


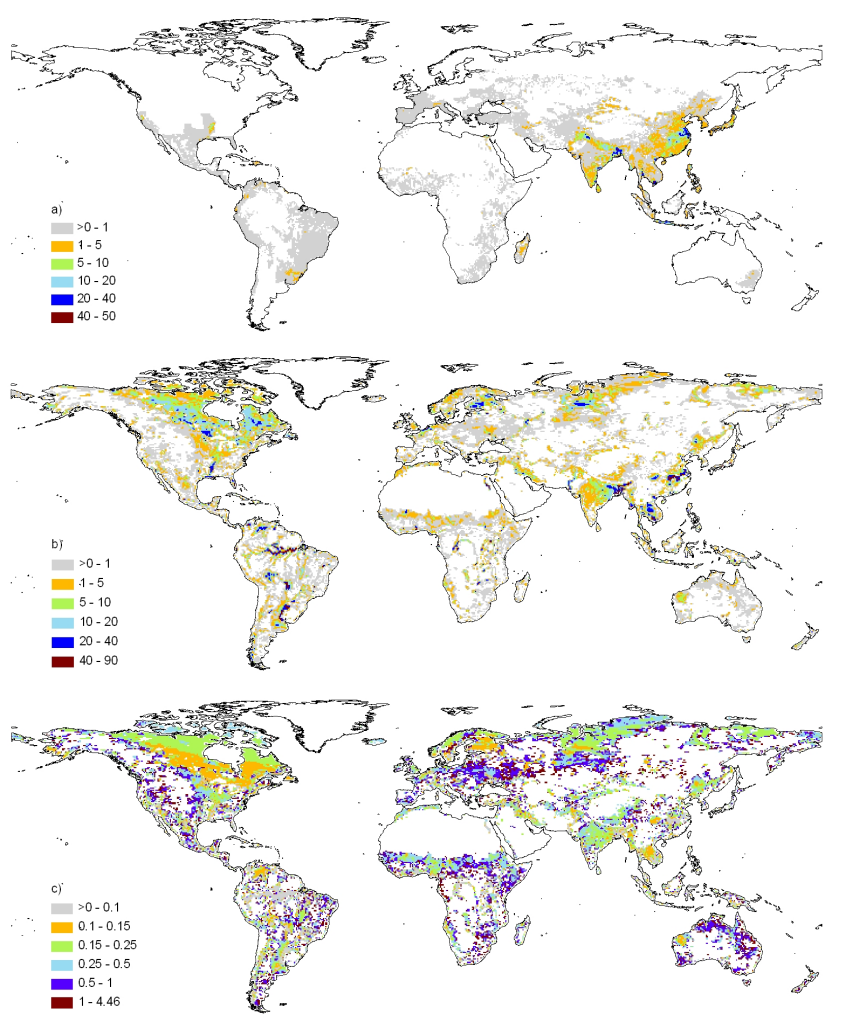

Fig. 1. Annual average growing area of irrigated rice, in percent of cell area (a), annual average naturally inundated area (average over all months between January 1993 and December 2004) based on Papa et al. (2010) and Portmann et al. (2010), in percent of cell area (b), and variability of naturally inundated areas as expressed by the coefficient of variation (c). Irrigated rice and surface water extent values are aggregated to $0.5^{\circ}$ cells.

\section{Comparison between satellite-based inundated areas and GLWD}

The wetlands in GLWD encompass "freshwater marshes, floodplains", "swamp forest, flooded forest" and "intermittent wetland/lake" as well as rivers, bogs, coastal wetlands, saline wetlands, and three classes of wetland complexes (Lehner and Döll, 2004). They cover approximately 9 million $\mathrm{km}^{2}$ or $7 \%$ of the global land area excluding Antarctica and Greenland. The first three types are seasonally inundated, covering 4.4 million $\mathrm{km}^{2}$ or $3.3 \%$ of the global land area. According to GLWD, lakes and reservoirs cover 2.7 million $\mathrm{km}^{2}$ or $2 \%$ of the global land area (Lehner and Döll, 2004). To compare GLWD to the satellite-derived NIA data set, GLWD was aggregated to $0.5^{\circ}$ grid cells, and all coastal cells, large lakes not included in NIA and wetland complexes of GLWD were removed. All wetland classes were aggregated and expressed as open water area in percent of cell area.

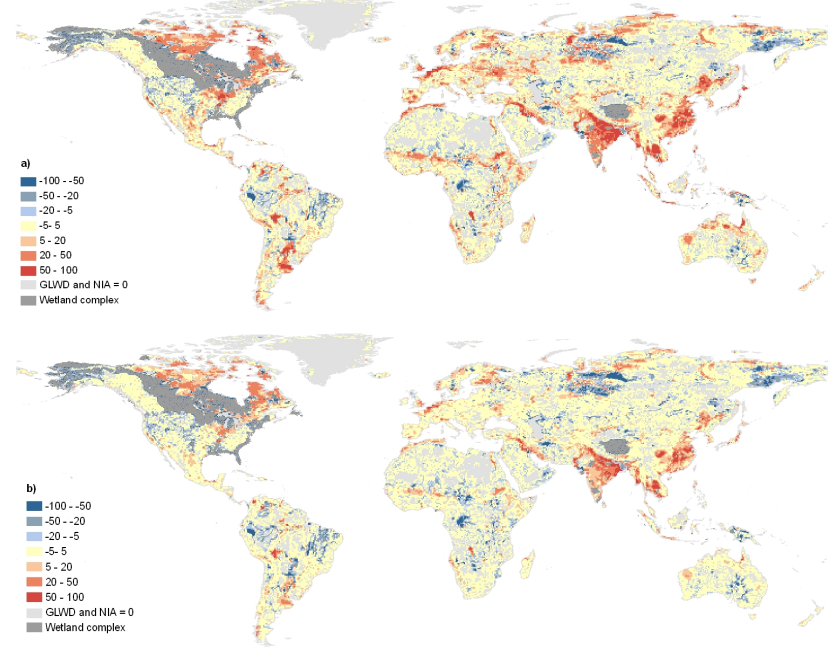

Fig. 2. Difference between the maximum value of naturally inundated areas (NIA) for each grid cell during 1993-2004 and the wetland extent of GLWD, in percent of cell area (a), and difference between the mean annual maximum of NIA and the wetland extent of GLWD, in percent of cell area (b).

GLWD is expected to represent a certain maximum extent of inundation as it is based on mapping of wetlands. Inundation extent of NIA should always be below the open water area of GLWD except possibly in case of extreme events. We compared GLWD areas to the maximum value of NIA for each grid cell during 1993 and 2004 (Fig. 2a) and to the mean annual maximum of NIA (mean of the maximum grid cell value of NIA of each of the 12 years) (Fig. 2b). For the considered $485740.5^{\circ}$ grid cells, GLWD includes 6.2 million $\mathrm{km}^{2}$ of open water, as compared to 10.1 million $\mathrm{km}^{2}$ for the maximum grid-specific NIA and 6.1 million $\mathrm{km}^{2}$ for the mean annual maximum of NIA. For $62 \%$ of the grid cells, GLWD and maximum NIA differ by less than 5\% (in units of percent of cell area), while GLWD areas are smaller than NIA for $26 \%$ of the grid cells (red areas in Fig. 2a). For the remaining 12\%, maximum NIA is smaller than GLWD areas (blue areas in Fig. 2a). When GLWD is compared to the mean annual maximum of NIA, in which extreme outliers are excluded and typical seasonal maxima are represented, the area with good agreement increases to $70 \%$, while the area where GLWD is smaller than NIA decreases to $16 \%$ (Fig. 2b).

The NIA values may be considerably smaller than GLWD if the maximum inundation extent during the time span in which the map representation of the wetland had been done was not reached during 1993-2004. This is likely the case in central Australia, where large salt lakes are included in GLWD that are flooded only once in a few decades. But there are also other reasons. For example, NIA does not include the extensive wetlands in the Congo basin, in particular the $60000 \mathrm{~km}^{2}$ large RAMSAR Grands Affluents wetland at the 


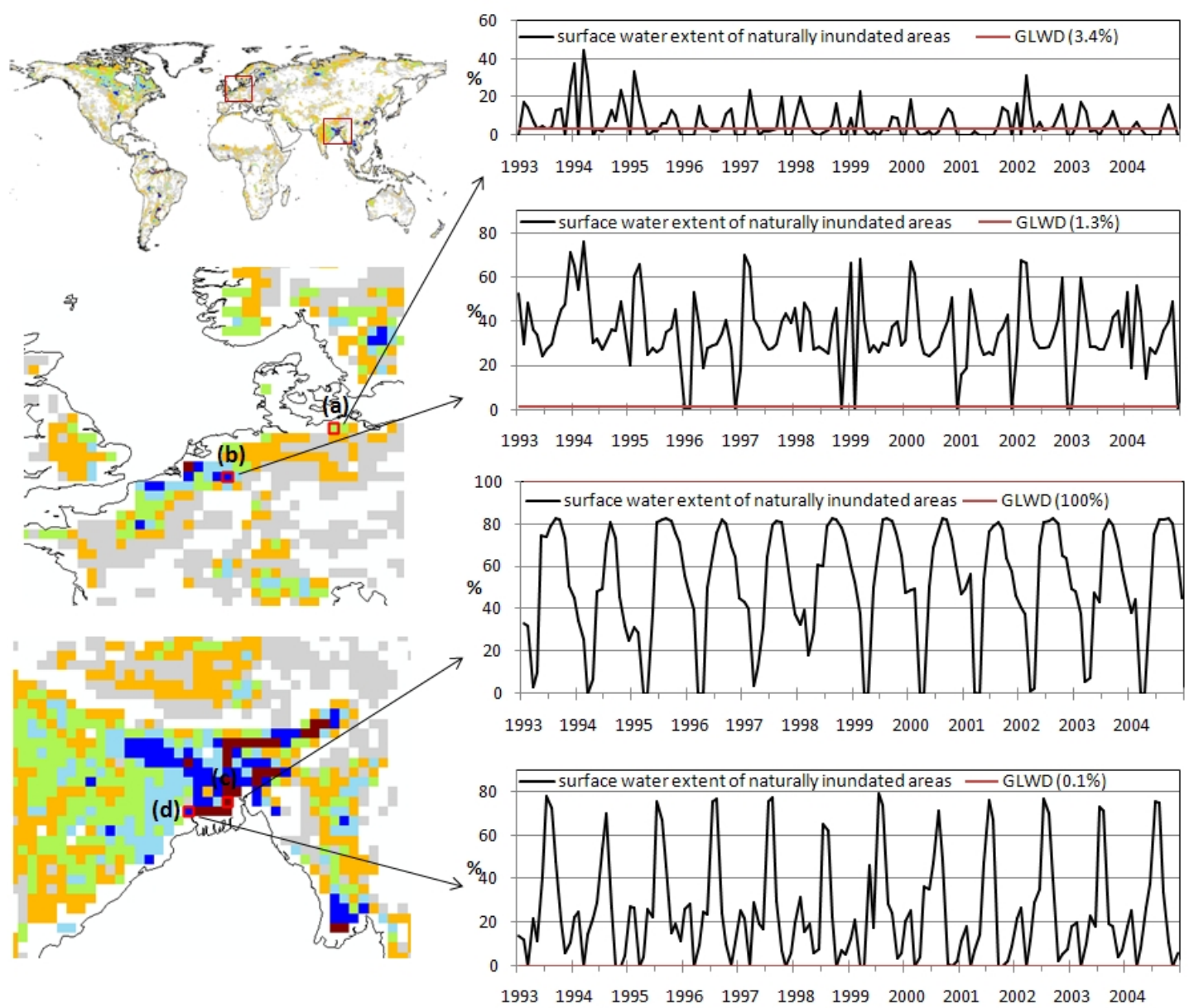

Fig. 3. Comparison of inundation extent (in percent of $0.5^{\circ}$ grid cell) of the time series of satellite-derived naturally inundated areas (19932004) and the wetland extent of GLWD (a constant) for four selected grid cells in Northwestern Europe and South Asia (right column). The left-hand column shows the location of the selected cells and the annual average of NIA (for legend see Fig. 1b).

middle reaches of the Congo (www.ramsar.org). This may be due to the presence of highly dense vegetation in the region which limits the ability of the multi-satellite technique to clearly capture the inundations.

Where NIA is larger than GLWD, this may be caused either by the omission of wetland areas in GLWD or by an erroneous identification of inundation by remote sensing. Satellite observation may overestimate the extent of actual open water areas because very wet soils may be wrongly identified as inundated. This is likely the case in Northwestern Europe (Netherlands, Belgium, Northern Germany, England, and Norway). In South and Southeast Asia, the problem of wet soils may contribute to the overestimation but it appears equally likely that GLWD is missing some wetlands there. For four selected grid cells in these problematic areas in Northwestern Europe and South Asia, GLWD open water extent (a constant) was compared to the satellite-derived time series of naturally inundated areas (Fig. 3). For the two cells over Europe, the satellite values appear to be implausibly high. Even though there are considerable amount of lakes in the cell close to the Baltic (Fig. 3a), the open water surface increases much less in spring as the satellite data, and it appears to be likely that the satellite algorithm misinterprets wet spring soils (after melting of snow) as inundated. The cell in Northwestern Germany (Fig. 3b) has an average of satellite-derived inundated area that exceeds the size of Lake Constance or Lake Balaton, such that these large areas may also represent wet soils. To understand the comparison for the two South Asian cells, please note that in GLWD, approximately the areas of Bangladesh is indicated as one large floodplain. The cell shown in Fig. 3c is located inside this GLWD floodplain area, the cell of Fig. 3d just outside. According to the satellite data, the latter is less extensively inundated during the monsoon season than the former, but it appears plausible that significant inundation during the monsoon season occurs also outside the floodplain area indicated in GWLD. 

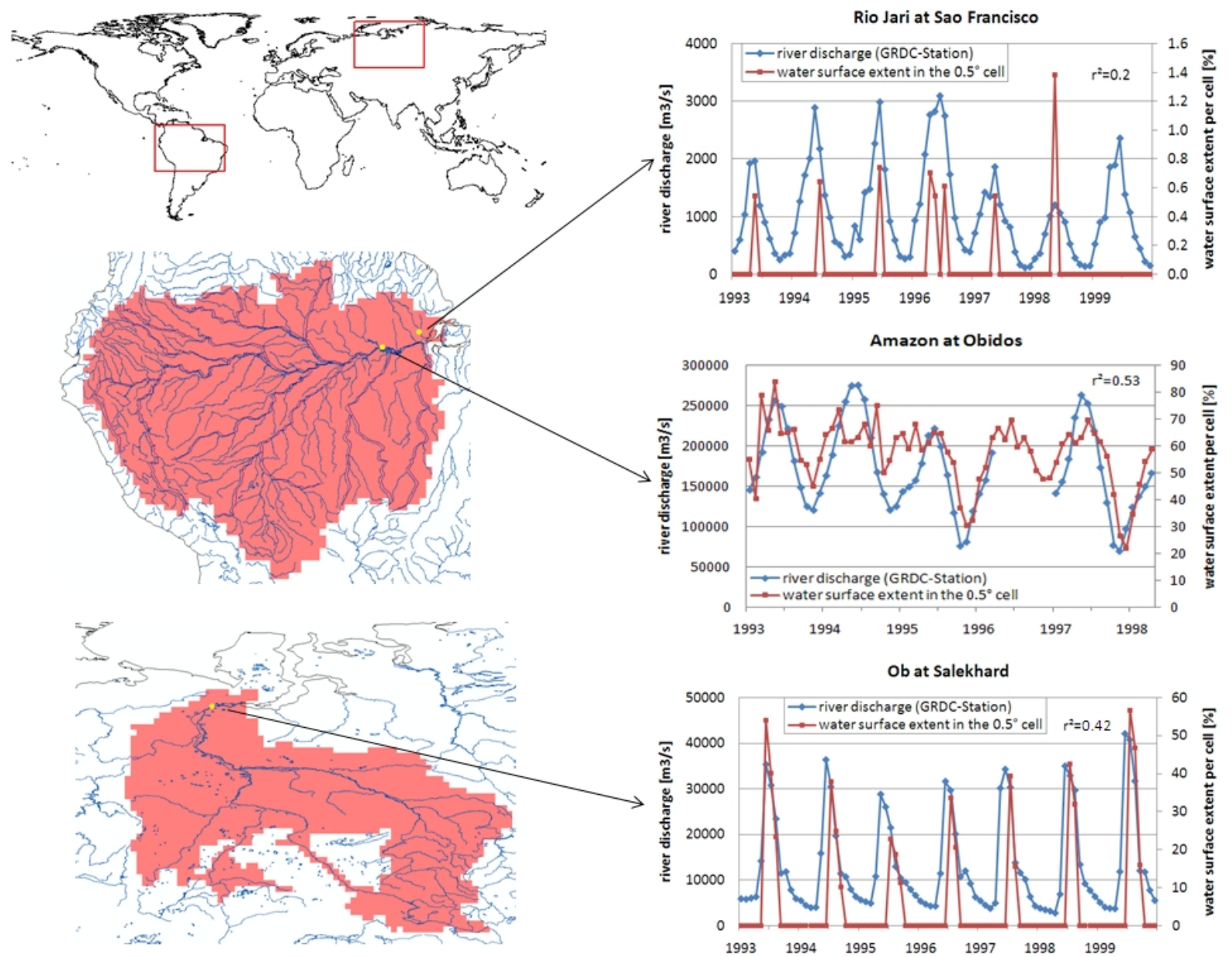

Fig. 4. Comparison of time series of observed river discharge (GRDC) at three gauging stations in the Amazon and Ob river basins and the extent of naturally inundated areas in the same $0.5^{\circ}$ grid cell.

\section{Relation between inundation area and river discharge}

Flow dynamics in floodplains are expected to depend on river discharge. In order to develop an algorithm that simulates the flow of water between the channel and the floodplain, it is useful to first analyze the relation between river discharge and inundation in the same grid cell. We compared observed river discharge obtained from the Global Runoff Data Centre GRDC (grdc.bafg.de) to the extent of naturally inundated areas at three gauging stations in the Amazon and $\mathrm{Ob}$ river basins (Fig. 4). Prigent et al. (2007) showed for the Amazon that their inundation estimates fit well to higher resolution SAR estimates, even though the number of pixels with low inundated area fraction was underestimated, and the number of pixels with very high fractions was overestimated. For the mainstream Amazon at Obidos, there is a high correlation of river discharge and inundated area in the grid cell. In the driest months, at least $20 \%$ of the cell area remains inundated. For a much smaller tributary, the Rio Jari at São Fran- cisco, flooding only occurs, typically during one month of the year, which is approximately the month with the highest discharge (time lag 0-1 month). The station Salekhard at the $\mathrm{Ob}$ river is located in the permafrost region and is dominated by snow. In case of snow, satellite estimates cannot be obtained. Open surface water is visible only from July to September, when also meltwater discharges are high and snow melt accumulates at the surface due to the low relief. Here, a high correlation of river discharge and open water extent can be observed but the large inundated areas may be primarily a function of temperature than of river discharge. Maximum inundation shows a time lag of $0-2$ months with respect to river discharge. Similar correlations between the temporal dynamics of surface water extent and river discharge have also been identified for the Amazon and Siberian rivers by Papa et al. (2007, 2008, 2010). 


\section{Conclusions}

In order to support the improved modeling of floodplain inundation in the global hydrological model WGHM, we combined a multisatellite data set of inundated areas (Papa et al., 2010) for the time period 1993-2004 with data on monthly irrigated rice areas around the year 2000 (Portmann et al., 2010). The resulting global-scale time series of monthly naturally inundated areas (NIA) (spatial resolution $0.5^{\circ}$ ), was compared to the static wetland extent in GLWD (used as input to WGHM) to better understand the validity and applicability of both data sets. We conclude that NIA can be used as an independent validation data set for dynamic floodplain models, but future work is required to identify areas where NIA overestimates inundation extent due to very wet soils, and where the satellite retrieval algorithm may not be able to identify inundated areas (e.g. in densely vegetated areas). GLWD mostly represents the maximum of surface water extent except in cases of extreme flooding but in some regions (e.g. South Asia) it is quite possible that wetland areas need to be added. To determine how flooding can be modeled as a function of computed river discharge, the relation between the dynamics of observed river discharge and naturally inundation extension was analyzed, and a correlation between river discharge and inundated area was found, with certain phase shifts of the maxima.

Based on this study, with a better understanding of the dynamics of naturally inundated areas, an improved model algorithm for dynamic floodplains in WGHM will be developed. The satellite-derived time series of naturally inundated areas will be used for validation.

Acknowledgements. We thank Felix Portmann for providing the data on irrigated rice areas.

Edited by: A. Wahren, F. Tavares Wahren, and K.-H. Feger Reviewed by: T. aus der Beek and another anonymous referee

\section{References}

Coe, M. T., Costa, M. H., and Howard, E. A.: Simulating the surface waters of the Amazon River basin: impacts of new river geomorphic and flow parameterizations, Hydrol. Process., 22, 2542-2553, 2008.

Decharme, B., Douville, H., Prigent, C., Papa, F., and Aires, F.: A new river flooding scheme for global climate applications: Off-line evaluation over South America, J. Geophys. Res., 113, D11110, doi:10.1029/2007JD009376, 2008.
Döll, P., Kaspar, F., and Lehner, B.: A global hydrological model for deriving water availability indicators: model tuning and validation, J. Hydrol., 270, 105-134, 2003.

Farr, T. G., Rosen, P. A., Caro, E., Crippen, R., Duren, R., Hensley, S., Kobrick, M., Paller, M., Rodriguez, E., Roth, L., Seal, D., Shaffer, S., Shimada, J., Umland, J., Werner, M., Oskin, M., Burbank, D., and Alsdorf, D.: The Shuttle Radar Topography Mission, Rev. Geophys. 45(2), 1-33, 2004.

Fiedler, K. and Döll, P.: Monthly and daily variations of continental water storage and flows, in: System Earth via GeodeticGeophysical Space Techniques, edited by: Gruber, Th., Flechtner, F., Güntner, A., Mandea, M., Rothacher, M., Schöne, T., and Wickert, J., Springer, in press, 2010.

Hunger, M. and Döll, P.: Value of river discharge data for globalscale hydrological modeling, Hydrol. Earth Syst. Sci., 12, 841861, doi:10.5194/hess-12-841-2008, 2008.

Lehner, B. and Döll, P.: Development and validation of a global database of lakes, reservoirs and wetlands, J. Hydrol., 296, 1-22, 2004.

Matthews, E., Fung, I., and Lerner, J.: Methane Emission From Rice Cultivation: Geographic and Seasonal Distribution of Cultivated Areas and Emissions, Global Biogeochem. Cy., 5, 3-24, doi:10.1029/90GB02311, 1991.

Papa, F., Prigent, C., Jimenez, C., Aires, F., Rossow, W. B., and Matthews, E.: Interannual variability of surface water extent at global scale, 1993-2004., J. Geophys. Res., 115, D12111, doi:10.1029/2009JD012674, 2010.

Papa, F., Prigent, C., and Rossow, W.: Monitoring Flood and Discharge Variations in the Large Siberian Rivers From a Multi-Satellite Technique, Surv. Geophys., 29, 297-317, doi:10.1007/s10712-008-9036-0, 2008.

Papa, F., Prigent, C., and Rossow, W. B.: Ob' River flood inundations from satellite observations: A relationship with winter snow parameters and river runoff, J. Geophys. Res, 112, D18103, doi:10.1029/2007JD008451, 2007.

Portmann, F., Siebert, S., and Döll, P.: MIRCA 2000 - Global Monthly Irrigated and Rainfed Crop Areas around the year 2000: A new high-resolution data set for agricultural and hydrological modelling, Global Biogeochem. Cy., 24, GB1011, doi:10.1029/2008GB003435, 2010.

Prigent, C., Papa, F., Aires, F., Rossow, W. B., and Matthews, E.: Global inundation dynamics inferred from multiple satellite observations, 1993-2000, J. Geophys. Res., 112, D12107, doi:10.1029/2006JD007847, 2007.

Prigent, C., Matthews, E., Aires, F., and Rossow, W. B.: Remote sensing of global wetland dynamics with multiple satellite data sets, Geophys. Res. Lett., 28, 4631-4634, 2001.

Werth, S. and Güntner, A.: Calibration analysis for water storage variability of the global hydrological model WGHM, Hydrol. Earth Syst. Sci., 14, 59-78, doi:10.5194/hess-14-59-2010, 2010. 